\title{
PECULIARITIES OF THE RELATIONSHIP OF A BENT TO FORGIVE WITH SOCIAL-PSYCHOLOGICAL COMPETENCE
}

\begin{abstract}
У статті представлено результати теоретико-емпіричного дослідження особливостей зв'язку схильності до прощення із соціально-психологічною компетентністю на українській вибірці з 235 осіб (119 жінок і 116 чоловіків): 136 студентів віком від 19 до 23 років, які здобувають першу вищу освіту, і 99 студентів віком від 24 до 45 років, які здобувають другу вищу освіту. Концепт «соціально-психологічна компетентність» розглядається як інтегративна характеристика особистості, яка визначає ефективну соціальну взаємодію, ефрективність соціалізації в профресійному середовищі та навколишньому світі, де важливими умовами продуктивного вирішення життєвих проблем є соціальна зрілість, суб'єктність позичії та соціальний інтелект. Концепт прощення розглядається як процес свідомої відмови особи від образи, гніву, ненависті, обурення, суму, зумовлених несправедливим ставленням інших людей до неї, і заміни негативних почуттів більш нейтральними й, нарешті, позитивними, такими як співчуття, жалість, що супроводжуються позитивними думками стосовно кривдника та припиненням його засудження. Виявлено значущі відмінності за схильністю до прощення в осіб із низьким i високим рівнем соціально-психологічної компетентності. Особи, які більшою мірою схильні до прощення, характеризуються більш розвиненим умінням розв'язувати міжособистісні проблеми й мають сорормовані сценарії поведінки в складних, консрліктних ситуаціях. Проаналізовано кореляції схильності до прощення з показниками комунікативної компетентності, товариськості, співробітництва, урівноваженості, агресивним типом міжособистісних стосунків, вираженістю симптомів тривоги та депресії. Виявлено позитивні значущі кореляційні зв'язки показника схильності до прощення з комунікативною компетентністю, товариськістю і співробітництвом як типом міжособистісних стосунків. Установлено, що особи, які схильні до прощення, характеризуються більшою стійкістю до стресу. Виявлено зворотній значущий кореляційний зв'язок показника схильності до прощення з агресивним типом міжособистісних стосунків. Установлено, що чим вище виражена в осіб схильність до прощення, тим меншою мірою їм властиві виражені симптоми депресії та тривоги.
\end{abstract}

5208.2020.16.36

\section{Кравчук С.Л.}

к.психол.н., доцент,

старший науковий співробітник лабораторії психології спілкування Інститут соціальної та політичної психології Національної академії педагогічних наук України
Ключові слова: схильність до прощення, соціально-психологічна компетентність, комунікативна компетентність, урівноваженість, співробітництво, тривога, депресія.

The article presents the results of a theoretical and empirical study of the relationship between the propensity to forgive and socio-psychological competence in the Ukrainian sample of 235 people (119 women and 116 men): 136 students aged 19 to 23 who receive their first higher education and 99 students aged 24 to 45 who are receiving a second higher education. The concept of socio-psychological competence is considered as an integrative characteristic of personality, which determines effective social interaction, the effectiveness of socialization in the professional environment and in the world, where important conditions for productive solutions to life problems are social maturity, subjectivity of position and social intelligence. The concept of forgiveness is seen as a process of a person's conscious rejection of resentment, anger, hatred, indignation, sadness caused by the unfair treatment of others, and the replacement of negative feelings with more neutral and, finally, positive, such as compassion, pity, accompanied by positive thoughts about the offender and the termination of his conviction. Significant differences in the propensity to forgive were found in people with low and high levels of socio-psychological competence. People who are more prone to forgiveness are characterized by a more developed ability to solve interpersonal problems and have developed scenarios of behavior in difficult, conflict situations. The correlations of the propensity to forgive with the indicators of communicative competence, sociability, cooperation, balance, aggressive type of interpersonal relationships, the severity of symptoms of anxiety and depression are analyzed. Positive significant correlations of the indicator of propensity to forgive with communicative competence, sociability and cooperation as a type of interpersonal relations were revealed. It has been found that people who are prone to forgiveness are more resistant to stress. A significant negative correlation was found between the propensity to forgive and the aggressive type of interpersonal relationships. It was found that the higher the propensity of people to forgive, the less they are characterized by severe symptoms of depression and anxiety.

Key words: propensity to forgive, socio-psychological competence, communicative competence, balance, cooperation, anxiety, depression.
Постановка проблеми. Для психологічної науки вкрай важливим та актуальним $€$ вивчення особливостей соціально-психологічної компетентності особистості як основи іï̈ ефективної адаптації, самореалізації, толерантності й самодостатності.

Останніми десятиліттями все більшої актуальності та значущості набуває проблема 
конструктивної взаємодії особистості з оточуючими людьми, важливими умовами якої $€$ здатність правильно розуміти поведінку людей, уміння обирати адекватні способи спілкування, визначати емоційні стани інших людей, орієнтуватися в соціальних ситуаціях.

У сучасному світі особистості, щоб бути затребуваною в суспільстві, необхідно швидко реагувати на зміни, актуалізувати свої можливості, постійно розвиватися й самовдосконалюватися. Саме тому для успішної життєдіяльності особистості в мінливих умовах життя важливою є її соціально-психологічна компетентність.

На нашу думку, феномен прощення відіграє важливу роль у забезпеченні психологічного благополуччя особистості, іï толерантності й вирішенні проблеми соціально-психологічного насильства.

Аналіз останніх досліджень і публікацій. Е.Л. Уортингтон (E.L. Worthington) [24] у дослідженнях виявив, що прощення кривдника передбачає відпущення негативних переживань, таких як гнів, ненависть, сум, образа тощо.

На думку зарубіжних учених Дж. Беррі (J.W. Berry) [12], Е. Муллет (Е. Mullet) [19], М. Гірард (M. Girard) [19], прощення доцільно розглядати як частковий прояв i результат механізмів соціального пізнання особи, оскільки здатність до прощення засновується на усвідомленні власних емоцій і здатності керувати ними, а також на здатності й готовності проявляти емпатію щодо кривдника.

У зарубіжних дослідженнях емпірично встановлено, що прощення та самопрощення значно знижує ризик виникнення симптомів посттравматичних розладів і суїцидальних намірів [18, с. 342].

Постановка завдання. Мета статті виявити й проаналізувати особливості зв'язку схильності до прощення із соціально-психологічною компетентністю.

Виклад основного матеріалу дослідження. Теоретичний аналіз концептів «соціально-психологічна компетентність» і «прощення» свідчить, що натепер у зарубіжній і вітчизняній психології немає єдиного їх визначення.

К. Рубін та А. Роуз-Креснор пропонують інформаційну концепцію соціальної компетентності, згідно з якою міра компетентності соціальної поведінки особистості визначається її індивідуальним досвідом, внутрішніми установками, емоційним станом, мотивацією та самооцінкою [7, с. 112]. На думку вчених, модель соціально компетентнісної поведінки включає такі компоненти: вибір цілі, оцінювання ситуації та повноти інформації, розроблення та прийняття стратегій, визначення, апробацію та оцінювання ефективності опти- мальної стратегії, повторення чи відмову від дії [7]. Цікаво, що К. Рубін та А. Роуз-Креснор включають у модель соціальної компетентності поняття соціальних сценаріїв як певних шаблонів, узгоджених дій у добре знайомих ситуаціях [7, с. 126].

В.М. Куніцина виокремлює в складі соціальної компетентності такі шість компонентів: комунікативна компетентність, вербальна компетентність, соціально-психологічна компетентність, міжособистісна орієнтація, его-компетентність, власне компетентність [4, с. 39]. Власне соціальна компетентність розуміється дослідницею як знання про соціальні інститути та структури, їх представників у суспільстві; уявлення про функціонування соціальних груп, сучасної кон'юнктури; уявлення про широту й вимоги сучасного репертуару рольової поведінки [4].

На окрему увагу заслуговує виокремлення В.М. Куніциною таких складників соціально-психологічної компетентності: уявлення про різноманіття соціальних ролей і способів взаємодії; уміння розв'язувати міжособистісні проблеми; вироблені сценарії поведінки в складних, конфліктних ситуаціях [4].

Ю. Мель уважає, що соціально компетентна особистість здатна:

1) приймати рішення стосовно себе самої та прагнути до розуміння власних почуттів і вимог;

2) забувати неприємні почуття та власну невпевненість;

3) уявляти, як треба досягати цілі найбільш ефективним способом;

4) правильно розуміти бажання, очікування й вимоги інших людей, зважувати й ураховувати їхні права;

5) аналізувати галузь, що визначається соціальними структурами та організаціями, роль ї представників і включати ці знання у власну поведінку;

6) розуміти, як з урахуванням конкретних обставин і часу поводити себе, ураховуючи обмеження соціальних структур і власні вимоги; бути уважним до інших людей [5, с. 66].

На думку С.А. Хазової [8, с. 32], соціально-комунікативна компетентність включає в себе здатність до колективних дій, до організації взаємодії (в широкому смислі); навички міжособистісного спілкування, уміння без насилля розв'язувати конфлікти; орієнтацію в соціальних ситуаціях, уміння обрати ефективну стратегію поведінки та адекватні способи спілкування, прагнення до соціальної взаємодії та здатність до роботи в неоднорідній команді; прихильність етичним цінностям.

Аналіз теоретичних джерел $[3 ; 4 ; 5 ; 6 ; 7 ; 8]$ дає змогу розглядати соціально-психологічну компетентність як інтегративну харак- 
теристику особистості, яка визначає ефективну соціальну взаємодію, ефективність соціалізації в професійному середовищі й навколишньому світі, де важливими умовами продуктивного рішення життєвих проблем є соціальна зрілість, суб'єктність позиції та соціальний інтелект.

На нашу думку, у цьому контексті надзвичайно вагомого значення набуває розуміння прощення як часткового прояву та результату механізмів соціального пізнання особи [12, с. $21 ; 19$, с. 118]. Також прощення розглядається дослідниками як дія, акт, відповідь, здібності, особистісна диспозиція, психічний стан, характеристики соціальних одиниць [11, с. 82; 14, с. 163].

Ф. Хайдер (F. Heider) уважає, що прощення доцільно розглядати як вибір особи відмовитися від мстивої поведінки [17, с. 112].

P. Еммонс (R. Emmons) розглядає прощення як особистісний конструкт високого рівня, за якого особи мають такі характеристики: можливість бути сприйнятливим до обставин, які зменшують гнів; наявність навичок контролювання емоцій; емпатія; смиренність; доброзичливість і прагнення перебувати в гармонійних стосунках [14, с. 162].

Дж.В. Беррі (J.W. Berry), Е.Л. Уортингтон (E.L. Worthington), Л.E. O'Коннор (L.E. O'Connor), Л. Парротт (L. Parrott), Н.Г. Уэйд (N.G. Wade)) переконані, що прощення $є$ диспозиціональною рисою особистості, тобто прощення $€$ рисою характеру [12, с. 17].

Дослідники Р. Енрайт (R. Enright) [9, с. 24] та Е. Гассін [1, с. 95] уважають, що прояв прощення в міжособистісних стосунках можна визначити як рішення, по-перше, відмовитися від негативних думок, емоцій і поведінкових проявів щодо кривдника, котрий незаслужено образив особу, по-друге, заохочувати позитивні думки, поведінкові прояви та емоції щодо того ж кривдника.

P. Енрайт (R. Enright) указує, що прощення вимагає відмови скривдженої людини від гніву й образи [15, с. 56].

На нашу думку, прощення доцільно розглядати як процес свідомої відмови особи від образи, гніву, ненависті, обурення, суму, зумовлених несправедливим ставленням інших людей до неї, і заміни негативних почуттів більш нейтральними й, нарешті, позитив- ними, такими як співчуття, жалість, що супроводжуються позитивними думками стосовно кривдника і припиненням його засудження.

у дослідженні взяли участь 235 осіб українські студенти (119 жінок і 116 чоловіків): 136 українських студентів віком від 19 до 23 років, які здобувають першу вищу освіту, і 99 українських студентів віком від 24 до 45 років, які здобувають другу вищу освіту.

Вибірка респондентів сформована з 5 українських університетів: Київського університету імені Бориса Грінченка, Національного педагогічного університету імені М.П. Драгоманова, Університету економіки і права «КРОК», Київського національного лінгвістичного університету, Київського національного університету імені Тараса Шевченка.

Участь респондентів у дослідженні була конфіденційною та добровільною.

У таблиці 1 представлено розподіл вибірки за статтю та віком.

Дослідження проведено з використанням етичних принципів і кодексів поведінки Американської психологічної асоціації (2010).

3 метою визначення особливостей зв'язку схильності до прощення із соціально-психологічною компетентністю нами застосовувалися такі психодіагностичні методи:

1) опитувальник «Шкала прощення як риси характеру» (автори: Дж.В. Беррі (J.W. Berry), Е.Л. Уортингтон (E.L. Worthington), Л.Е. О'Коннор (L.E. O’Connor), Л. Парротт (L. Parrott), Н.Г. Уэйд (N.G. Wade)) [12];

2) методика вимірювання комунікативної та соціальної компетентності (автор: В.М. Куніцина) [4];

3) фрайбурзький особистісний опитувальник (автори: Дж. Фаренберг (J. Fahrenberg), Р. Хемпел (R. Hampel), Х. Зелг (H. Selg));

4) методика «Діагностика міжособистісних стосунків» (автор: Т. Лірі);

5) методика «Діагностикадепресії та тривоги» (автор: Л.P. Дерогатис (L.R. Derogatis)) [13]

На основі методики вимірювання комунікативної та соціальної компетентності В.М. Куніциної ми сформували дві групи учасників дослідження:

1 група - особи, які характеризуються низьким рівнем соціально-психологічної компетентності (68 осіб);

Розподіл вибірки за статтю та віком

Таблиця 1

\begin{tabular}{|l|c|c|c|c|c|c|}
\hline \multirow{2}{*}{ Групи } & \multicolumn{2}{|c|}{ 19-23 роки } & \multicolumn{2}{c|}{ 24-45 роки } & \multicolumn{2}{c|}{ Разом } \\
\cline { 2 - 7 } & № & \% & № & \% & № & \% \\
\hline Жінки & 84 & 35,75 & 35 & 14,89 & 119 & 50,64 \\
\hline Чоловіки & 52 & 22,12 & 64 & 27,24 & 116 & 49,36 \\
\hline Разом & 136 & 57,87 & 99 & 42,13 & 235 & 100,00 \\
\hline
\end{tabular}


2 група - особи, які характеризуються високим рівнем соціально-психологічної компетентності (72 особи).

На основі однофакторного дисперсійного аналізу виявлено відмінності в схильності до прощення в респондентів першої та другої груп. Отримані результати представлено в таблиці 2.

Отримані результати свідчать, що існують значущі відмінності між першою та другою групами респондентів за схильністю до прощення на рівні значущості $p<0,001$ (див. таблицю 2).

Особи, які більшою мірою схильні до прощення, характеризуються більш розвиненим умінням розв'язувати міжособистісні проблеми та мають сформовані сценарії поведінки в складних, конфліктних ситуаціях.

Емпірично визначено кореляційні зв'язки схильності до прощення 3 індивідуально-психологічними характеристиками (див. таблицю 3).

Нами емпірично встановлено позитивні значущі кореляційні зв'язки показника схильності до прощення з комунікативною компетентністю $(r=0,407, p<0,01)$, товариськістю $(r=0,316, p<0,01)$ і співробітництвом як типом міжособистісних стосунків $((r=0,393$, $\mathrm{p}<0,01)$. Отримані результати свідчать, що особи, які схильні до прощення, володіють складними комунікативними навичками й уміннями, сформованими адекватними вміннями в нових соціальних структурах, знаннями культурних норм та обмежень у спілкуванні, знаннями звичаїв, традицій, етикету у сфері спілкування; добре орієнтуються в комунікативних засобах; характеризуються вихованістю, товариськістю, вираженою потребою в спілкуванні та постійною готовністю до задоволення цієї потреби; характеризуються схильністю до співробітництва, гнучкістю й компромісністю під час вирішення проблем і в конфліктних ситуаціях.

Виявлено прямий значущий кореляційний зв'язок показника схильності до прощення 3 показником урівноваженості ( $r=0,426$, p< 0,01). Особи, які схильні до прощення, характеризуються більшою стійкістю до стресу.

у зарубіжній психології представлено стрес-і-копінг модель прощення [16; 21; 24]. Результати емпіричних досліджень свідчать, що особи, які не навчилися прощати, мають значно більше захворювань, які пов'язані зі стресом [22, с. $190 ; 23$, с. 164]. Також виявлено, що самопрощення знижує ризик виникнення симптомів посттравматичних розладів і суїцидальних намірів [20].

В емпіричному дослідженні нами виявлено зворотній значущий кореляційний зв'язок показника схильності до прощення з агресивним типом міжособистісних стосунків (див. таблицю 3). Значення коефіцієнта кореляції Ч. Спірмена за двома показниками дорівнює $-0,274(p<0,01)$.

У зарубіжних дослідженнях показано, що завдяки прощенню здійснюється заміна негативних почуттів на співчуття й терпимість [20]. Також у зарубіжних дослідженнях емпірично встановлено, що прощення передбачає відпущення гніву, ненависті, суму, образи [22, с. $190 ; 24$, c. 12$]$.

За коефіцієнтом кореляції Ч. Спірмена виявлено зворотні значущі зв'язки прощення як риси характеру з тривогою та депресією (див. таблицю 3). Відповідно, значення коефіцієнтів кореляції Ч. Спірмена дорівнюють 0,311 $(\mathrm{p}<0,01)$ та $-0,426(\mathrm{p}<0,01)$ (див. таблицю 3).

Отримані кореляційні зв'язки свідчать, що чим вище виражена в осіб схильність до про-

Відмінності в схильності до прощення

\begin{tabular}{|c|l|c|c|c|}
\hline Показник & \multicolumn{1}{|c|}{ Групи } & $\begin{array}{c}\text { Середнє } \\
\text { значення }\end{array}$ & $\begin{array}{c}\text { Стандартне } \\
\text { відхилення }\end{array}$ & $\begin{array}{c}\text { Рівень } \\
\text { значущості }\end{array}$ \\
\hline \multirow{2}{*}{ Схильність до прощення } & 1 група & 20,132 & 7,655 & 0,000 \\
\cline { 2 - 4 } & 2 група & 35,597 & 7,187 & $(\mathrm{p}<0,001)$ \\
\hline
\end{tabular}

Таблиця 3

Взаємозв'язок схильності до прощення з індивідуально-психологічними характеристиками

\begin{tabular}{|l|c|c|}
\hline \multicolumn{1}{|c|}{ Показники } & Коефіцієнт кореляції & Рівень значущості \\
\hline Товариськість & 0,316 & $\mathrm{p}<0,01$ \\
\hline Комунікативна компетентність & 0,407 & $\mathrm{p}<0,01$ \\
\hline Співробітництво & 0,393 & $\mathrm{p}<0,01$ \\
\hline Агресивний тип міжособистісних стосунків & $-0,274$ & $\mathrm{p}<0,01$ \\
\hline Урівноваженість & 0,426 & $\mathrm{p}<0,01$ \\
\hline Тривога & $-0,311$ & $\mathrm{p}<0,01$ \\
\hline Депресія & $-0,426$ & $\mathrm{p}<0,01$ \\
\hline
\end{tabular}


щення, тим меншою мірою їм властиві виражені симптоми депресії та тривоги.

у зарубіжних дослідженнях установлено, що інтервенції, засновані на концепції прощення, сприяють покращенню показників суб'єктивного психологічного благополуччя, зменшенню вираженості симптомів тривоги й депресії [10, с. 456].

В емпіричному дослідженні виявлено прямий значущий зв'язок інтегрального показника готовності до прощення за методикою «Діагностика готовності до прощення» (автор: С.Л. Кравчук) із самоприйняттям та особистісним зростанням [2, с. 81].

На нашу думку, схильність до прощення може захистити особистість від розвитку травматичного стресу, депресивних симптомів, дає можливість особистості позитивно адаптуватися до несприятливих наслідків важких життєвих ситуацій.

Висновки 3 проведеного дослідження. Виявлено значущі відмінності за схильністю до прощення в осіб із низьким і високим рівнем соціально-психологічної компетентності. Особи, які більшою мірою схильні до прощення, характеризуються більш розвиненим умінням розв'язувати міжособистісні проблеми та мають сформовані сценарії поведінки в складних, конфліктних ситуаціях.

Виявлено позитивні значущі кореляційні зв'язки показника схильності до прощення з комунікативною компетентністю, товариськістю та співробітництвом як типом міжособистісних стосунків.

Установлено, що особи, які схильні до прощення, характеризуються більшою стійкістю до стресу.

Виявлено зворотній значущий кореляційний зв'язок показника схильності до прощення з агресивним типом міжособистісних стосунків.

Установлено, що чим вище виражена в осіб схильність до прощення, тим меншою мірою їм властиві виражені симптоми депресії та тривоги.

Практична цінність дослідження полягає в тому, що отримані результати можуть бути використані в психологічній консультації, у психотерапії, а також у процесі подальшого дослідження проблеми психології прощення.

Перспективу дослідження вбачаємо в теоретико-емпіричному дослідженні психологічних особливостей зв'язку прощення з компонентами соціально-психологічної компетентності.

\section{ЛІТЕРАТУРА:}

1. Гассин Э.А. Психология прощения. Вопросы психологии. 1999. № 4. С. 93-104.

2. Кравчук С.Л. Методика «Діагностика готовності до прощення». Психологічний часопис : науковий журнал. Київ : Інститут психології імені Г.С. Костюка Національної академії педагогічних наук України, 2020. № 3. Вип. 6. С. 74-83.

3. Кудинова И.Б. Социальный интеллект: психологические аспекты становления : монограсрия. Новосибирск : НГПУ, 2007. 223 с.

4. Куницына В.Н., Казаринова Н.В., Погольша В.М. Межличностное общение : учебник для вузов. Санкт-Петербург : Питер, 2003. 544 с.

5. Мель Ю. Социальная компетентность как цель психотерапии: проблемы образа Я в ситуации социального перелома. Вопросы психологии. 1995. № 5. С. 61-68.

6. Михайлова Е.С. Социальный интеллект. Концепции, модели, диагностика. Санкт-Петербург : Изд-во С-Петерб. ун-та, 2007. 266 с.

7. Рубин К.Х., Роуз-Крэснор Л. Решение межличностной проблемы и социальная компетентность в поведении детей. Межличностное общение / сост. и общ. ред. Н.В. Казариновой, В.М. Погольши. Санкт-Петербург : Питер, 2001. 512 с.

8. Хазова С.А. Компетентность конкурентоспособного специалиста по фризической культуре и спорту. Москва : Академия естествознания, 2010. $91 \mathrm{c}$.

9. Энрайт Р. Духовное развитие прощения. Москва : Академия, 1991. 220 с.

10. Akhtar S., Dolan A., Barlow J. Understanding the relationship between state forgiveness and psychological wellbeing: A qualitative study. Journal of Religion and Health. 2017. Vol. 56 (2). P. 450-463.

11. Baskin T.W. \& Enright R.D. Intervention Studies on Forgiveness: A Meta-Analysis. Journal of Counseling \& Development. 2004. Vol. 82 (1). P. 79-90.

12. Berry J.W., Worthington E.L., O'Connor L.E., Parrott L.I. \& Wade N.G. Forgivingness, vengeful rumination, and affective traits. Journal of Personality. 2005. Vol. 73. P. 1-43.

13. Derogatis L.R. Brief Symptom Inventory (BSI) - 18: Administration, scoring and procedures manual. Minneapolis, MN : NCS Pearson, 2001. 47 p.

14. Emmons R.A. Personality and forgiveness. McCullough M.E., Pargament K.I. \& Thoresen C.E. Forgiveness: Theory, research, and practice. New York: Guilford Press, 2000. P. 156-175.

15. Enright R.D. Forgiveness Is a Choice: A Step-byStep Process for Resolving Anger and Restoring Hope. Washington, DC : American Psychological Association, 2001. 299 p.

16. Harper Q., Worthington E.L., Griffin B.J., LavelockC.R., HookJ.N., VranaS.R.\&GreerC.L. Efficacy of a workbook to promote forgiveness: a randomized controlled trial with university students. Journal of Clinical Psychology. 2014. Vol. 70 (12). P. 1158-1169.

17. Heider F. The psychology of interpersonal relations. New York, NY : Wiley, 1958. 322 p.

18. Lijo K.J. Forgiveness: Definitions, Perspectives, Contexts and Correlates. Journal of Psychology \& Psychotherapy. 2018. Vol. 8 (3). P. 342.

19. Mullet E., Girard M. Developmental and cognitive points of view on forgiveness. McCullough M.E., Pargament K.I. \& Thoresen C.E. Forgiveness: Theory, research, and practice. New York : Guilford Press, 2000. P. 111-132. 
20. Raj P., Elizabeth C.S., Padmakumari P. Mental health through forgiveness: Exploring the roots and benefits. Cogent Psychology. 2016. Vol. 3 (1).

21. Strelan P., Covic T. A Review of Forgiveness Process Models and A Coping Framework to Guide Future Research. Journal of Social and Clinical Psychology. 2006. Vol. 25 (10). P. 1059-1085.

22. VanderWeele T.J. Is Forgiveness a Public Health Issue? American Journal of Public Health. 2018. Vol. 108 (2). P. 189-190.
23. Wade N.G. \& Worthington E. L. Jr. In Search of a Common Core: A content Analysis of Interventions to Promote Forgiveness. Psychotherapy: Theory, Research, Practice, Training. 2005. Vol. 42 (2). P. 160-177.

24. Worthington E.L.Jr., Kurusu T.A., Collins W., Berry J.W., Ripley J.S. \& Baier S.N. Forgiving usually takes time: A lesson learned by studying interventions to promote forgiveness. Journal of Psychology and Theology. 2000. Vol. 28 (1). P. 3-20. URL: https:// psycnet.apa.org/record/2000-15404-001. 